\title{
The Interaction of Sport and Law: Where Has It Been, Where Is It Now, and Where Is It Going?
}

\author{
Andrew T. Pittman \\ Baylor University
}

\section{INTRODUCTION}

Prior to the 1960s, there would have been little to say about legal issues in sport. Since then, however, legislators, administrators, and courts have expanded the scope of the laws they create and enforce.

How has this expanded judicial scrutiny affected sport? Several hundred colleges and universities have eliminated sports such as flag football, noncompetitive diving, canoeing, and hiking because of liability costs (Brimelow \& Spenser, 1989). Day care centers and playgrounds have been closed, and limitations have been placed on extramural school activities (Chambers, Ross, \& Kozubowski, 1987). By the mid 1980s, there were no longer any American manufacturers of trampolines (Lubell, 1987). Today, only 2 of the 20 American football helmet manufacturers of the 1960s are still in business (Raines, 1991).

What does this portend for the future? So that we may better predict and shape the future of sport and law, we need to know the history of that interaction. This article surveys the interaction of sport and law from ancient times to the present, then suggests an approach for the future.

\section{E ANCIENT TIMES}

The history of sports law can be traced to the origins of sport. Nafziger (1988) stated that organized sports competition dates back at least to the ancient Egyptians, and as early as 1829 B.C. athletic competitions took place in Ireland. A central concept of athletic competition has always been that its participants agree to compete within stated rules of accepted play, rules which for the most part reflect the societal values of a particular culture. The first interactions of sport and law were the violations of these rules which were intended to preserve the integrity of the game (Sloan, 1983). For example, the early Olympic Games were designed to promote better relations among the varied and often hostile Greek city-states and, 
in order to accomplish a sense of fairness throughout the competition, strict rules were passed and enforced by the judges (Schubert, Smith, \& Trentadue, 1986). Among the issues covered by the Olympic rules were the enforcement of racial and gender discrimination, legal controls on the character and conduct of athletes, sports-related injuries, and the status and compensation of athletes (Scanlan \& Cleveland, 1981), all of which reflected the values of Greek society.

After Greece was conquered by the Romans and as Christianity was spread into Europe by the conquering Romans, the values reflected in sport began to change; some thought for the worse. The games began to be challenged, then legally regulated. Christians deplored the homicidal element. Tertullian's treatise On Spectacles, written around 200 A.D., was the most hostile of the Christian attacks on the Roman games (Baker, 1982). Theodosius, one of the early Christian emperors, abolished the Olympic Games in 394 A.D. because of their pagan influence (Rice, 1929).

Sport in ancient Rome had traditionally served two primary purposes: to train soldiers and to provide entertainment for the masses (Coakley, 1990). Because so many Romans held only part-time jobs or were unemployed, frequent holidays were given so that the workers could enjoy such spectacles as gladiatorial contests, bull and bear baiting, chariot races, boxing matches, and contests pitting humans against animals. Some of these events also served as a way of eliminating the socially undesirable from Roman society. Even conservative Romans regulated sport. Since many Romans believed that Greek athletics were a corrupting influence on Roman youth, for example, the law required Roman athletes to wear clothing during competition, unlike the practice of nudity among Greek athletes (Baker, 1982).

\section{- MIDDLE AGES TO RENAISSANCE}

During the Middle Ages, from approximately 500 to 1400 A.D., Roman influence declined. Because of attacks from many tribes, the Roman Empire became smaller. Local games and tournaments played by the peasants and influenced by local customs and the Roman Catholic Church began to emerge. The tournaments were similar to those of the Romans in that militarily-oriented sporting events - archery, jousting, sword fighting - began to emerge. Many types of ball games - harpastum, episkyros, kegels - which contained the roots of many contemporary ball games, were played by the peasants (Baker, 1982). However, these games were unpopular with many of the nobility. In 1314, King Edward II banned soccer, a ban not enforced in the rural areas of England until 1349, when King Henry III saw soccer as a threat not only to law and order, but also to national security, because the energies of young men were not being spent on archery practice (Falla, 1981). The ban was not revoked for 200 years. From March, 1457, in the reign of King James II of Scotland, through the Third Parliament of James IV of Scotland in 1491, bans were enacted on at least three occasions against sports, especially golf and soccer, because of their interference with archery practice (Mandell, 1948). In 1511, King Henry VIII of England forbade bowling for all except himself and certain members of his court (Schwendener, 1942).

Over the next hundred years, various prohibitions against sport participation on the Sabbath became consolidated into a powerful Puritan movement effectively 
prohibiting participation in any sport on that day. Around 1600, the Prince of Purpoole, Sir Henry James of Norfolk, pardoned many offenses, but he refused to pardon people who owned or frequented houses or places where unlawful exercises such as vaulting, bowling, or forbidden shooting took place (Brown, 1921). Upon returning to England and hearing the complaints of his followers, King James I in 1618 issued his Declaration of Sports which allowed recreational activities on the Sabbath after Sunday services (Guttmann, 1988). In 1633, Charles I reissued his father's declaration which was later damned and ordered to be burned by Parliament (Guttmann, 1988). In 1660, sixteen years after sports activities were banned on Sundays, Charles II proclaimed them legal.

\section{AMERICAN COLONIAL PERIOD}

Restrictive attitudes toward sport were carried to colonial America by the Puritan settlers. In 1609, politicians in New England banned soccer (Falla, 1981). On June 22, 1611, Sir Thomas Dale, the governor of Virginia, in his code of laws included a decree banning sport on the Sabbath (Lucas \& Smith, 1978). On December 25, 1621, Governor William Bradford of Massachusetts reacted to the playing of sports, specifically pitching the bar and stool-ball, by condemning them (Guttmann, 1988). In 1647, the General Court of the Massachusetts colony outlawed shuffleboard; three years later, it prohibited bowling (Guttmann, 1988). That same court on August 30, 1653, passed a law that made play, sport, and aimless sauntering on Sunday a misdemeanor (Lucas \& Smith, 1978). The town fathers in Boston in 1657 imposed a fine of 20 shillings against anyone playing folk football (Falla, 1981). From 1695 through 1794, various Philadelphia courts and Pennsylvania legislatures banned disorderly sports and play, especially on Sunday (Lucas \& Smith, 1978). For instance, when the borough of Pittsburgh was organized on April 22,1794 , laws were immediately passed which prohibited engaging in billiards, bowling, bullet playing, cock fighting, horseracing, and shuffleboard (Brynn, 1968). However, the unlawful sports were practiced openly and without much protest (Brynn, 1969).

In spite of all the legal prohibitions, sport in America continued to grow. Colonists of New Amsterdam, (i.e., New York), like those of the Virginia tidewater country, felt little or no restraint from on high, no urge of conscience which prohibited pleasure and leisure. Recreational and sports activities forced their way into the strongholds of Puritanism (Schwendener, 1942). With the liberalization in social attitudes and the adoption of the doctrine of "social gospel" by Protestant religious groups, sport began to flourish (Spears \& Swanson, 1983).

\section{Q THE NINETEENTH CENTURY -THE AGE OF ORGANIZATION}

The nineteenth century was characterized by organization. Intercollegiate (Spears \& Swanson, 1983) and interscholastic sports (Jable, 1986) had their beginnings in the early and latter portions of that century, respectively. Baseball was the first sport to receive school support with the organization of the Worcester, Massachusetts, High School Baseball Club in 1859 (Schwendener, 1942). In 1866, California became the first state in the nation to require physical education in its 
public high schools (Hoepner, 1970). Baseball became the first organized professional sport with the formation of the Cincinnati Red Stockings in 1869 (Schubert et al., 1986). On April 22, 1879, the National Association of Amateur Athletes of America was formed but was disbanded 10 years later and succeeded by the Amateur Athletic Union, now called The Athletic Congress, on January 21, 1888 (Falla, 1981). The first public playgrounds were built, and physical education in higher education was also instituted during this century (Spears \& Swanson, 1983). Also, during the late 1890's, the American Olympic Committee, a forerunner to the United States Olympic Committee, was organized (Falla, 1981).

There were relatively few sports lawsuits during the nineteenth century. Van der Smissen (1990) noted two cases regarding public parks, three concerning immunity of public schools, and two immunity cases involving university athletic associations. In the earliest case reported in the area of tort liability of school districts, their officers, agents, and employees (Century Edition of the American Digest, 1903), the Supreme Court of Massachusetts ruled that the defendant school district was not negligent in providing a safe place for the injured plaintiff to attend school (Bigelow v. Inhabitants of Randolph, 1860). In an 1880 lawsuit, Perkins v. Directors, a young boy who had been suspended from school for hitting a ball through a school house window pane, was allowed to return to school even though his family had refused to pay the $\$ 3$ to replace the window. Several lawsuits involved contractual issues and the reserve clause in professional baseball (American Assn. Ball Club v. Pickett, 1890; Columbus B.B. Club v. Reiley, 1891; Harrisburg B.B.Clubv.Athletic Assn., 1890; Metropolitan Exhibition Co. v. Ewing, 1890; Metropolitan Exhibition Co. v. Ward, 1890; Philadelphia Ball Club v. Hallman, 1890).

Some of the rules of baseball were also a reflection of the societal values of the time, a theme that is prevalent today. One particular value in question was racial discrimination. From 1858, with the formation of the National Association of Baseball Players, until 1867, blacks were allowed to play for clubs that belonged to that organization (Ashe, 1988). After 1867, blacks were banned but continued to play professional baseball until 1884 and were excluded from participation until Jackie Robinson's entry in 1947 (Tygiel, 1984).

\section{THE EARLY TWENTIETH CENTURY - CONTINUED ORGANIZATION AND RESPONSE TO SOCIETAL VALUES}

The early part of the twentieth century continued to be a time of organization and of response to societal values. Football had become such a brutal sport by 1903 that several state legislatures tried unsuccessfully to ban it (Falla, 1981). On October 9, 1905, President Roosevelt, reacting to the violence in football, summoned several football leaders to the White House and issued them an ultimatum -reform the game or abolish it. As a result of this meeting and a subsequent conference, the Intercollegiate Athletic Association of the United States, a forerunner of the National Collegiate Athletic Association, was formed (Falla, 1981). In an early case (Kinzer v. Directors of Independent School District of Marion, 1906), the suspension of a student from high school for playing football was upheld because of the high incidence of injuries, a legitimate societal concern. In a baseball 
case involving an injured patron (Blakely $v$. White Star Line, 1908), the Supreme Court of Michigan reversed a circuit court's decision by ruling that an owner of premises must exercise ordinary care to keep the premises reasonably safe. Five years later, in Cedar Rapids, Iowa, some citizens became so enraged over the playing of baseball on the Sabbath that they sought to have the mayor and chief of police removed from office because of their refusal to prohibit that practice (State v. Roth, 1913). One year later, the Supreme Court of Wisconsin heard John Curkeet's suit against his school district for an alleged breach of contract (Curkeet v. Joint School District, 1914). Some of the charges were that Mr. Curkeet, as director of the school's football team, had revoked permission to play a game with another high school and also had serious altercations with some women teachers regarding the management of the girls' basketball team.

In the early 1900s in Texas, the University Interscholastic League (UIL) and the Southwest Conference (SWC) were founded. This began in 1909, when Dr. S.E. Mezes, president of the University of Texas, organized the Extension Bureau, which in 1913 was renamed the UIL (University Interscholastic League, 1990-91). The Southwest Intercollegiate Athletic Conference held its initial meeting on May 6, 1914 , at the Oriental Hotel in Dallas. The organization was completed at a second meeting at the Rice Hotel in Houston on December 8, 1914, and adopted its current name in May 1916 (Southwest Conference Press Release, n.d.).

The present-day National Federation of State High School Athletic Associations (originally called the Midwest Federation of State High School Athletic Associations) had its beginning in a meeting in Chicago on May 14, 1920 (Forsythe, 1948). The various state high school associations operated for many years with almost no judicial interference. The first reported challenge to a state high school athletic association's authority came in 1938 in the Morrison v. Roberts case. The Supreme Court of Oklahoma upheld the suspension of a football player who had violated one of the association's rules. For the next two decades, only three other cases were reported (Doerhoff, 1973).

Partially as a response to the poor physical condition of American soldiers in World War I, beginning around 1918 and continuing through the late 1920s some of the most far-reaching events in physical education of the twentieth century occurred (Brownell \& Hagman, 1951). During that time, over 40 states passed or revised legislation requiring local boards of education to maintain programs of physical education according to state standards or authorizing use of school tax funds for this purpose. Over $95 \%$ of the public school population was affected. As could be expected, this legislation directly and indirectly resulted in many lawsuits. On April 11, 1927, the Supreme Court of Arizona (Alexander v. Phillips) upheld the issue of $\$ 80,000$ in bonds by the Phoenix Union high school district of Maricopa County to construct a stadium. Williams and Brownell (1937) mention many lawsuits and legislation which arose as a result of state-mandated physical education.

From the 1940s through the early 1950 s in the United States, several prominent physical educators (Brownell \& Hagman, 1951; Nash, Moench, \& Saurborn, 1951; Voltmer \& Esslinger, 1949) wrote concerning the legal problems of physical educators. Voltmer and Esslinger (1949) expressed a concern among physical 
educators about the legal implications of injuries which occurred in physical education programs. They continued by saying that the most common sources of accidents which led to liability suits were unsafe facilities, defective equipment, and improper supervision. Nash et al. (1951) noted the trend toward holding boards of education and municipalities responsible for negligence. In a number of instances, the authors stated, vigorous physical education activities had been eliminated and school yards locked because of the fear of losing a lawsuit. That same year, Brownell and Hagman briefly mentioned law and administration. Their primary focus was state legislatures and their role in law-making. In spite of the increase in legal activity, the concern for the legal education of teachers and administrators was deficient until approximately 1950 (Arnold, 1983).

\section{THE SIXTIES - ERA OF GROWTH AND CHANGE}

In part because of the development of new facilities and equipment and the subsequent increases in participation, the decade of the 1960s saw a rise, which continued into the 1970s, in the number of pupils injured in physical education programs (Amold, 1983). Drowatzky (1977) listed the following reasons for the high number of injuries in physical education: inadequate equipment, nonexistent equipment, inadequate facilities, and too many participants in an undersized area. However, according to Langerman (1964), this increase in injuries did not necessarily result in a corresponding increase in lawsuits because of the doctrines of charitable and sovereign immunity and because of the reluctance of the injured to sue the coach or school. The legal climate changed, however, when a New Jersey court awarded an injured gymnast over $\$ 1,200,000$ (Miller v. Cloidt and the Board of Education of the Borough of Chatham, 1964), an award which was reported to be the highest negligence award in history, and which terrified educators everywhere. This award was subsequently reduced to $\$ 300,000$ and the case was settled out of court, but it created change in the pattern of physical education in many states (Appenzeller, 1970).

During the 1960s and 1970s, changes in societal values continued to influence the interactions of sport and law. On July 2, 1964, Public Law 88-352, the Civils Rights Act of 1964 (1964a, 1964b), in Title VI and VII prohibited discrimination in federally-assisted programs and mandated equal employment opportunity, respectively. Title VI stipulated that no person in the United States, regardless of race, color, or national origin, could be excluded from participation in, denied the benefits of, or be subjected to discrimination under any program or activity receiving federal financial assistance. Title VII stated that it was unlawful to have discriminatory employment practices based on an individual's race, color, religion, sex, or national origin. Two laws passed in the 1970s had similar impact on sports. Title IX (Education Amendments of 1972) stated that it was unlawful to deny benefits, exclude from participation, or discriminate against any person in the United States on the basis of sex under any education program or activity receiving federal financial assistance. The Education for All Handicapped Children Act of 1975 provided for a free appropriate public education for all handicapped children. These various acts expanded the opportunities for sport participation to many who had previously been denied such opportunity. Alsoduring this time, the Association 
for Intercollegiate Athletics for Women (AIAW) was established (Spears \& Swanson, 1983). However, the AIAW dissolved shortly after its three-year lawsuit against the National Collegiate Athletic Association (Association for Intercollegiate Athletics for Women $v$. NCAA, 1984). Because of these new enactments, a considerable number of lawsuits were filed, especially in the areas of discrimination against handicapped individuals (Appenzeller, 1983) and gender discrimination (Tokarz, 1986).

\section{THE SEVENTIES TO THE PRESENT - EXPANSION OF SPORTS LAW}

Since the 1970s, the scope of sports law has expanded. Waicukauski (1982) reported that the most active area of sports litigation has been liability for sports injuries. In addition, he stated that the passage of Title IX and the Amateur Sports Act of 1978, and the legal system's expansion of the concepts of due process and equal protection, have caused litigation to reach epidemic proportions. Probably the most important sports law legislation of the 1980s involved Title IX.

Until the U.S. Supreme Court's decision in Grove City College v. Bell (1984), the Office of Civil Rights (OCR), the federal agency with enforcement authority for these laws, determined that if any portion of a college or university received federal funds, the entire institution was covered. The Supreme Court reversed this determination, ruling that only the program actually receiving the funding was bound by the law's nondiscrimination requirements. On March 22, 1988, after several attempts, the United States Congress reversed the Grove City College result with the passage of the Civil Rights Restoration Act of 1987 which again made an entire institution subject to the requirement of these nondiscrimination laws, even if only a portion of the institution received federal funds. When Grove City College was decided, the OCR closed, limited, or suspended 64 investigations into genderdiscrimination complaints against universities, more than half of which dealt with sports (Oberlander, 1989). In the three years following the passage of the Restoration Act, 163 complaints were filed with the OCR (Harris, 1991).

College sports administrators have become concerned over the courts' increasingly liberalized definition of negligence (Lederman, 1988). Athletes have begun to sue each other for their allegedcriminal actions (Horrow, 1980). Sports have moved from the playing fields to the courts (Fotiades, 1989). As Appenzeller (1975) has stated, athletics and law have entered a new era. Koehler (1987) believes that if law is a response to social need, then legal issues in sport activities reflect an attempt at resolution of social conflict in that area; and, as long as sport remains a part of society, this relationship will continue.

\section{FUTURE OF SPORT AND LAW}

Most commentators share the opinion voiced by Waicukauski (1982) that law will continue to play an important role in sports, and that as long as sports participation continues to expand, so too will the level of legal activity associated with sport. Does this mean the increasing restriction of sport-a return to the forbidding rules and narrowing regulations of earlier times? Futurists are divided on this question (Appenzeller \& Appenzeller, 1980). Jeffries (1985) says that the 
legal system is not intent on destroying sport but that the primary concern is the health and well-being of the participants. Waicukauski (1982) predicts that in time there will be diminished legal activity in some areas of sports where the law becomes settled and people adjust their behavior to comply. On the other hand, Massengale (1989) does not necessarily see an optimistic future for sport and law. He says that professionals in the area of sport law do not seem to be trying to determine what that future will be, and if their level of consciousness regarding the significance of the future is not raised, then some segments of American sport may disappear. To paraphrase George (1990), the time has arrived when society must strike the most effective balance between reason and passion regarding sports and the law.

We must act now, or once again see some sports vanish. Legislators, judicial officials, attorneys, coaches, educators, parents, and participants must all work together to ensure that everyone has an opportunity to participate in as safe an environment as possible. Some type of legal education - coursework, conferences, seminars, workshops, etc. - should be required of sport administrators to preserve sports. The alternative may be a scenario that is unpalatable to all - the demise of sport.

\section{References}

Alexander v. Phillips, 254 P. 1056 (1927).

Amateur Sports Act of 1978, PL 95-606, 36 U.S.C. sec 371.

American Assn. Ball Club v. Pickett, 8 Pa Co. Ct. Rep. 232 (1890).

Appenzeller, H. (1970). From the gym to the jury. Charlottesville, VA: Michie.

Appenzeller, H. (1975). Athletics and the law. Charlottesville, VA: Michie.

Appenzeller, H. (1983). The right to participate. Charlottesville, VA: Michie.

Appenzeller, H., \& Appenzeller, T. (1980). Sports and the courts. Charlottesville, VA: Michie.

Arnold, D.E. (1983). Legal considerations in the administration of public school physical education and athletic programs. Springfield, IL: C. Thomas Publisher.

Ashe, A. R., Jr. (1988). A hard road to glory: A history of the African-American athlete from 1619-1918. New York: Warner.

Association for Intercollegiate Athletics for Women v. NCAA, 735 F. 2d 577 (1984). 
Baker, W.J. (1982). Sports in the western world. Totowa, N.J.: Rowman and Littlefield.

Bigelow v. Inhabitants of Randolph, 80 Mass. 541 (1860).

Blakely v. White Star Line, 118 N.W. 482 (1908).

Brimelow, P., \& Spencer, L. (1989). The plaintiff attorney's great honey rush. Forbes, 144 (8), 197-200, 202-203.

Brown, B. (1921). Law sports at gray's inn (1594). New York: Author.

Brownell, C.L., \& Hagman, E. P. (1951). Physical education-foundations and principles. New York: McGraw-Hill.

Brynn, S. S. (1968). Some sports in Pittsburgh during the national period, 17751860, part 1. The Western Pennsylvania Historical Magazine, 51(4), 345 363.

Brynn, S. S. (1969). Some sports in Pittsburgh during the national period, 1775 1860, part 2. The Western Pennsylvania Historical Magazine, 51(1), 57 79.

Century Edition of the American Digest. (1903). Volume 43. St. Paul, MN: West.

Chambers, R.L., Ross, N.V., \& Kozubowski, J. (1987). Insurance types and coverages: Knowledge to plan for the future (with a focus on motor skill activities and athletics). The Physical Educator, 44 (1), 233-240.

Civil Rights Act of 1964, Pub. L. 88-352, Title VI, 42 U.S.C. sec. 2000 d et. seq. (1964a).

Civil Rights Act of 1964, Pub. L. 88-352, Title VII, 42 U.S.C. sec. 2000 e et. seq. (1964b).

Civil Rights Restoration Act of 1987, PL 100-259, 102 Stat. 28 (1988).

Coakley, J.J. (1990). Sport in society: Issues and controversies. St Louis: Times Mirror/Mosby.

Columbus B.B. Club v. Reiley, 25 Week. Bull. 385, 11 Ohio Dec. 272. (1891).

Curkeet v. Joint School District No. 2, 149 N.W. 708 (1914).

Doerhoff, D.C. (1973). State high school association and the law. 2J.L.\& Ed. 41.

Drowatzky, J. (1977). On the firing line: Negligence in physical education, 6 J.L. \& Ed. 481 .

Education Amendments of 1972, Pub. L. No. 92-318, Title IX, 86 Stat. 373-75 (1972) as amended, 20 U.S.C. Secs. 1681-88. 
Education for All Handicapped Children Act of 1975, Pub. L. 94-142, 89 Stat. 773 (1975) as amended 20 U.S.C. Secs. 1401-1461 (1975 ed. \& Sup. III 1979).

Falla, J. (1981). NCAA: The voice of college sports. Mission, KS; National Collegiate Athletic Association.

Forsythe, C.E. (1948). The administration of high school athletics (2nd ed.). New York: Prentice-Hall.

Fotiades, J.M. (1989). You're the judge! How to understand sports, torts, and courts. Worcester, MA: Edgeworth \& North Books.

George, G. (1990, March). National trends in sports litigation. Paper presented at the American Alliance for Health, Physical Education, Recreation, and Dance National Convention, New Orleans, LA.

Grove City College v. Bell, 465 U.S. 555, 104 S.Ct. 1211, 79 L. Ed. 2d 516 (1984).

Guttmann, A. (1988). A whole new ballgame: An interpretation of American sports. Chapel Hill, NC: University of North Carolina.

Harris, C.J. Reform of women's intercollegiate athletics, 20 Cap. U.L. Rev. 691, 699 (Footnote 71).

Harrisburg B.B. Club v. Athletic Assn., 8 Pa. Co. Ct. Rep 337 (1890).

Hoepner, B.J. (1970). John Swett's experience with physical exercise at the Rincon school: Foundation for the first state physical education law in the U.S. The Research Quarterly, 41(3), 365-370.

Horrow, R.B. (1980). Sports violence: The interaction between private lawmaking and the criminal law. Arlington, VA: Carrollton Press.

Jable, J.T. (1986). High school athletics: History justifies extracurricular status. JOPERD, 57(2), 61-68.

Jeffries, S.C. (1985). Sport law study guide. Champaign, IL: Human Kinetics.

Kinzer v. Directors of Independent School District of Marion, 129 Iowa 441, 105 N.W. 686 (1906).

Koehler, R.W. (1987). Law: Sport activity and risk management. Champaign, IL: Stipes.

Langerman, S. (1964). 7 Am. Jur., 2D Trials Section 1.

Lederman, D. (1988, July 27). Colleges and officials face huge costs when injured athletes sue for negligence. The Chronicle of Higher Education, pp. 1, 2122.

Lubell, A. (1987). Insurance, liability, and the American way of sport. The Physician and Sportsmedicine, 15 (9), 192-200. 
Lucas, J.A., \& Smith, R.A. (1978). Saga of American sport. Philadelphia, PA: Lea \& Febiger.

Mandell, R.D. (1948). Sport: A cultural history. New York: Columbia University.

Massengale, J.D. (1989). A look at the future of sports law. Legal Issues in Sport, 1(1), 4-11.

Metropolitan Exhibition Co. v. Ewing, 42 F. 198, 24 Abb. N.C. 419 (1890).

Metropolitan Exhibition Co.v. Ward, 24 Abb. N.C. 393, 9 N.Y. Supp. 779 (1890).

Millerv. Cloidt and the Board of Education of the Borough of Chatham, No. L 7241 62, (N.J. Super Ct. 1964).

Morrison v. Roberts, 183 Okla 359, 82 P. 2 d 1023 (1938).

Nafziger, J.A.R. (1988). International sports law. Dobbs Ferry, NY: Transnational.

Nash, J.B., Moench, F.J., \& Saurborn, J.B. (1951). Physical education: Organization and administration. New York: S.S. Bames.

Oberlander, S. (1989, June 21). Advocates for women's sports say 1988 civil-rights act has not brought hoped-for equity with men. The Chronicle of Higher Education, pp. A23-A24.

Perkins v. Directors, 56 Iowa 476, 9 N.W. 356 (1880).

Philadelphia Ball Club v. Hallman, 8 Pa. Co. Ct. Rep 57. (1890).

Raines, J.T. (1991). Adventure programs-Can the risk be taken? JOPERD, 62 (1), 64-67.

Rice, E.A. (1929). A brief history of physical education. New York: A.S. Barnes.

Scanlan, J., \& Cleveland, G. (1981). The past as prelude: The early origins of modem American sports law, 8 Ohio N.U.L. Rev. 433.

Schubert, G.W., Smith, R.K., \& Trentadue, J.C. (1986). Sports law. St. Paul, MN: West.

Schwendener, N. (1942). A history of physical education in the United States. New York: A.S. Barnes.

Sheppard v. The State, 1 Tex. Ct. App. 304 (1876).

Sloan, P.S. (1983). The athlete and the law. New York: Oceana.

Southwest Conference Press Release. (n.d.). Dallas, TX: Southwest Conference.

Spears, B., \& Swanson, R.A. (1983). History of sport and physical activity in the United States (2nd ed.). Dubuque, IA: William C. Brown. 
State v. Roth, 144 N.W. 339 (1913).

Tokarz, K. (1986). Women, sports, and the law: A comprehensive research guide to sex discrimination in sports. Buffalo, NY: William S. Hein.

Tygiel, J. (1984). Baseball's great experiment: Jackie Robinson and his legacy. New York: Vantage Books.

University Interscholastic League. (1990-91). Constitution and contest rules (81st ed.). Austin, TX: University of Texas.

van der Smissen, B. (1990). Legal liability and risk management for public and private entities. Cincinnati, $\mathrm{OH}$ : Anderson.

Voltmer, E.F., \& Esslinger, A.A. (1949). The organization and administration of physical education. New York: Appleton-Century-Crofts.

Waicukauski, R.J. (Ed.). (1982). Law and amateur sports. Bloomington, IN: Indiana University.

Williams, J.F., \& Brownell, c.L. (1937). The administration of health and physical education. Philadelphia, PA: W.B. Saunders. 